\section{Effects of NAA, AVG, and 1-MCP on Ethylene Biosynthesis, Preharvest Fruit Drop, Fruit Maturity, and Quality of 'Golden Supreme' and 'Golden Delicious' Apples}

\author{
Rongcai Yuan ${ }^{1}$ and David H. Carbaugh \\ Virginia Polytechnic Institute and State University, Alson H. Smith, Jr. \\ Agricultural Research and Extension Center, 595 Laurel Grove Road, \\ Winchester, VA 22602
}

Additional index words. fruit abscission, Malus $\times$ domestica, plant growth regulators

\begin{abstract}
Effects of naphthaleneacetic acid (NAA), aminoethoxyvinylglycine (AVG), and 1-methylcyclopropene (1-MCP) alone or in combination on fruit ethylene production, preharvest fruit drop, fruit quality, and fruit maturation were examined in 'Golden Supreme' and 'Golden Delicious' apples (Malus $\times$ domestica Borkh.). In 'Golden Supreme' apples, the combination of two applications of AVG and one application of NAA 3 and 1 week, respectively, before the anticipated optimum harvest date synergistically inhibited fruit ethylene production and delayed fruit drop and ripening. Compared with one or two applications of AVG, the combination of one application of AVG and two applications of NAA had much lower preharvest fruit drop, although there was no significant difference in fruit ethylene production among these treatments. In 'Golden Delicious' apples, 1-MCP at $396 \mathrm{mg} \cdot \mathrm{L}^{-1}$ had a better effect in delaying fruit drop than did AVG at $125 \mathrm{mg} \cdot \mathrm{L}^{-1}$ or NAA at $20 \mathrm{mg} \cdot \mathrm{L}^{-1}$ when they were applied a week before the optimum harvest date. The combination of NAA and 1-MCP or AVG was more effective in delaying fruit drop than were NAA, 1-MCP, or AVG alone. Fruit ethylene production was inhibited by 1-MCP and AVG but not by NAA. 1-MCP and AVG delayed fruit ripening, whereas NAA increased fruit ripening as determined by fruit firmness and starch.
\end{abstract}

Preharvest apple (Malus $\times$ domestica Borkh.) fruit drop, which occurs before fruit develop optimum red color, maturity, or size, usually causes a serious economic loss. Conversely, picking fruit before adequate maturity may lead to poor storability and poor fresh and processed fruit quality. Early harvest can also result in lower yields and prices because fruit will increase in weight $5 \%$ to $7 \%$ per week and price is based on larger fruit sizes (Byers and Eno, 2002). Ideally, plant growth regulators should hold fruit on the tree for an additional 3 weeks past optimum harvest date to improve fruit size, color, and crop value by as much as $20 \%$ while maintaining fruit quality (Byers and Eno, 2002).

It has been suggested that the balance between plant growth promoters and inhibitors controls fruit abscission and ripening (Addicott, 1982; Brown, 1997; Yuan et al., 2002, 2003). Auxin plays a very important role in the control of fruit abscission (Osborne, 1989). Application of synthetic auxins

\footnotetext{
Received for publication 7 Aug. 2006. Accepted for publication 25 Sept. 2006.

We acknowledge the financial support of the Virginia Agricultural Council. We also acknowledge the assistance of Grace Engelman.

${ }^{1}$ To whom reprint requests should be addressed; e-mail yuan@vt.edu.
}

reduced preharvest fruit drop of apples (Gardner et al., 1940; Marini et al., 1993) and oranges (Gardner et al., 1950; Zur and Goren, 1977). One application of naphthalene acidic acid (NAA) may delay apple fruit drop for $\approx 10$ to $14 \mathrm{~d}$ after treatment, and repeated applications of NAA delay fruit abscission more than single applications (Batjer and Moon, 1945; Marini et al., 1993). However, fruit softening is usually increased by two applications of NAA or warm weather after the first application (Smock and Gross, 1947). On the contrary, application of ethephon, an ethylene-releasing compound, effectively promoted mature fruit abscission and ripening in apples (Edgerton and Blanpied, 1970), oranges (Yuan et al., 2002), and cherries (Bukovac et al., 1969), whereas AVG, an inhibitor of ethylene biosynthesis, reduced fruit ethylene production and preharvest fruit drop and delayed fruit ripening in apples (Autio and Bramlage, 1982; Bangerth, 1978; Byers et al., 2005; Greene, 2005; Schupp and Greene, 2004).

1-Methylcyclopropane (1-MCP), an inhibitor of ethylene action, has been used to delay postharvest ripening of climacteric fruit such as apples (Fan et al., 1999; Sisler and Serek, 1997), peaches (Kluge and Jacomino, 2002), avocado (Jeong et al., 2002), and tomatoes (Jeong et al., 2002). 1-MCP, a gas, has been formulated as a powder that releases 1-MCP when mixed with a buffered base and is also widely used in the cut flower industry (Blankenship and Dole, 2003). Recently, a sprayable formulation of 1-MCP became available for use in the field.

The purpose of this investigation was to study the effect of NAA alone or in combination with ethylene biosynthesis inhibitor AVG or ethylene action inhibitor 1-MCP and time of application on control of preharvest fruit drop and maintenance of on-tree fruit quality in 'Golden Supreme' and 'Golden Delicious' apples.

\section{Materials and Methods}

Expt. 1: naphthalene acidic acid and aminoethoxyvinylglycine on ethylene production and preharvest drop of 'Golden Supreme' apples. Sixty-six 5-year-old 'Golden Supreme'/M9 trees located at the Alson H. Smith, Jr. Agricultural Research and Extension Center, Winchester, Va., were selected and grouped into six blocks of 11 trees each in Aug. 2005. A randomized complete block design with six replications was used. AVG (Retain; Valent BioSciences Corp., Libertyville, Ill.) at $125 \mathrm{mg} \cdot \mathrm{L}^{-1}$, NAA (Fruitone N; AMVAC Corp., Newport Beach, Calif.) at $20 \mathrm{mg} \cdot \mathrm{L}^{-1}$, and 2,4,5-TP at $20 \mathrm{mg} \cdot \mathrm{L}^{-1}$ alone or in combination were applied on 5 Aug., 3 weeks before anticipated harvest (WBAH), or on 19 Aug., 1 WBAH. $2,4,5-\mathrm{TP}$ at $20 \mathrm{mg} \cdot \mathrm{L}^{-1}$ served as a positive control. All spray solutions contained Silwet77 silicone surfactant (Loveland Industries, Loveland, Colo.) at $0.624 \mathrm{~mL} \cdot \mathrm{L}^{-1}$. Spray treatments were applied to runoff with a low-pressure hand-wand sprayer. One tree in each block was not sprayed and served as a control. Fruit fallen under each tree were counted and removed periodically until 24 Oct. when the fruit remaining on the trees were harvested and cumulative drop calculated.

Six fruit were collected from each tree on 4 Aug., 19 Aug., 22 Aug., 2 Sept., and 23 Sept. to determine fruit ethylene production. Fruit were enclosed in a 3.785-L container and incubated for $3 \mathrm{~h}$. One milliliter of gas sample was withdrawn from the sealed container through the rubber septum affixed to a lid and ethylene concentration was measured with a gas chromatograph equipped with an activated alumina column and FID detector (model 3700; Varian, Palo Alto, Calif.).

To determine fruit maturity and quality, 10 fruit were sampled from each tree on 23 Aug., 30 Aug., and 20 Sept. Fruit background color was rated on a scale of 0 to 4 , in which $0=$ green and $4=$ yellow (Byers and Eno, 2002). Fruit with stem end cracks were counted. Fruit firmness was measured on two sides of each fruit with an Effegi penetrometer (model FT 327; McCormick Fruit Tech, Yakima, Wash.) with an 11.1-mm tip. Soluble solids concentration (SSC) was measured with an Atago handheld refractometer (model N1; McCormick Fruit Tech) using 
a composite sample of juice resulting from penetrometer testing of all replicates of each treatment. Each apple fruit was cut in half transversely and flesh starch was evaluated by dipping half of each apple in iodine solution for $\approx 15 \mathrm{~s}$. The degree of staining was rated on a scale of 0 to 8 , in which $0=$ staining of the entire cut surface and $8=$ absence of staining (Poapst et al., 1959).

Expt. 2: naphthalene acidic acid, 1methylcyclopropene, and aminoethoxyvinylglycine on ethylene production and preharvest drop of 'Golden Delicious' apples. Forty-eight 6-year-old 'Golden Delicious'/M9 located at the Alson H. Smith, Jr. Agricultural Research and Extension Center, Winchester, Va., were selected and grouped into six blocks of eight trees each in Sept. 2005. A randomized complete block design with six replications was used. NAA at 20 $\mathrm{mg} \cdot \mathrm{L}^{-1}$ alone or in combination with $\mathrm{AVG}$ at $125 \mathrm{mg} \cdot \mathrm{L}^{-1}$ or a sprayable formulation of 1 MCP (Rohm and Haas Co., Spring House, $\mathrm{Pa}$.) at $396 \mathrm{mg} \cdot \mathrm{L}^{-1}$ were applied on $21 \mathrm{Sept} ., 1$ WBAH (28 Sept.). All spray solutions contained surfactant Silwet L-77 at 0.624 $\mathrm{mL} \cdot \mathrm{L}^{-1}$. Spray treatments were applied to runoff with a low-pressure hand-wand sprayer. One tree in each block was not sprayed and served as a control. Fruit fallen under each tree were counted and removed periodically until 3 Nov. when the fruit remaining on the trees were harvested and cumulative drop calculated. Six fruit were collected from each tree on 21 Sept., 29 Sept., 25 Oct., and 10 Nov. to determine fruit ethylene production. Fruit ethylene was measured as described previously.

Ten fruit were sampled from each tree on 28 Sept. and 24 Oct. for fruit quality evaluations (fruit firmness, SSC, starch staining, fruit background color, fruit diameter and weight). Fruit background color, firmness, SSC, and flesh starch were measured as described previously.

Statistical analyses. Statistical analyses included analysis of variance and Duncan's multiple range test. Statistical Analysis Systems Software for PC (SAS Institute, Cary, N.C.) was used to analyze these data.

\section{Results}

Expt. 1: naphthalene acidic acid and aminoethoxyvinylglycine on ethylene and preharvest drop of 'Golden Supreme'. AVG alone or in combination with NAA or $2,4,5$ TP effectively reduced preharvest fruit drop (Fig. 1). One application of NAA at 20 $\mathrm{mg} \cdot \mathrm{L}^{-1} 3$ or 1 WBAH effectively delayed fruit drop for $\approx 14 \mathrm{~d}$, whereas two applications of NAA effectively delayed fruit drop $\approx 20 \mathrm{~d}$. The delay of fruit drop by AVG was more persistent than that of NAA or 2,4,5-TP. There was no significant difference in fruit drop control between one and two applications of AVG. One application of the combination of AVG and NAA or 2,4,5-TP 3 WBAH had no synergistic effect on fruit drop control. However, the combination of one application of AVG $3 \mathrm{WBAH}$ and two applications of NAA had the best fruit drop control effect $(\approx 6 \%$ fruit drop on 24 Oct., $\approx 2$ months after the anticipated harvest date) followed by the combination of 2 applications of AVG and one application of NAA $1 \mathrm{WBAH}(\approx 10 \%$ fruit drop on 24 Oct.).

Ethylene production of fruit from control trees was very low before fruit ripening and rapidly increased when fruit started to ripen (22 Aug. and 2 Sept.) (Table 1). 2,4,5-TP increased fruit ethylene production and advanced the onset of fruit ethylene climacteric, whereas AVG inhibited fruit ethylene production and delayed the onset of fruit ethylene climacteric. There was no significant difference in fruit ethylene production between one and two applications of AVG as used alone. Addition of AVG reduced fruit ethylene production stimulated by NAA or 2,4,5-TP. The combination of two applications of AVG and one application of NAA $1 \mathrm{WBAH}$ had the lowest fruit ethylene production on 23 Sept., whereas one or two applications of AVG alone was not different from the combination of one application of AVG 1 WBAH and two applications of NAA. The combination of AVG and NAA applied 3 WBAH had higher fruit ethylene production than that of one application of AVG 3 WBAH and two applications of NAA, but both had lower fruit ethylene production than the untreated control.

Fruit from trees treated with NAA or 2,4,5-TP were softer compared with fruit from control trees on 20 Sept., whereas addition of AVG slowed the loss of fruit firmness incited by NAA or 2,4,5-TP (Table 2 ). There was no significant difference in fruit firmness between one and two applications of NAA on 20 Sept. Addition of AVG also reduced NAA- or 2,4,5-TP-caused starch degradation as indicated by lower starch rating. Fruit weight increased with time. AVG and NAA alone had no effect on SSC, but the combinations of one application of AVG 1 WBAH and one or two applications of NAA reduced SSC (Table 3). Fruit background color was enhanced by NAA or 2,4,5TP but reduced by addition of AVG. Fruit stem end cracking was also reduced by the addition of AVG.

Expt. 2: naphthalene acidic acid and aminoethoxyvinylglycine on ethylene and preharvest drop of 'Golden Delicious'. NAA, 1-MCP, and AVG alone or in combination effectively delayed preharvest fruit drop (Fig. 2). The efficacy of NAA alone for fruit drop control was of shorter duration than that of 1-MCP or AVG alone. 1-MCP was more effective in delaying preharvest fruit drop than was AVG. The combination of NAA and AVG or 1-MCP was more effective in the control of preharvest fruit drop than NAA, AVG, or 1-MCP alone. Ethylene production of fruit from control trees was very low before 29 Sept. and rapidly increased thereafter (Fig. 3). Fruit ethylene production was inhibited by addition of AVG or 1-MCP, but NAA had little or no effect on fruit ethylene production. The effect of 1-MCP on fruit ethylene production disappeared,

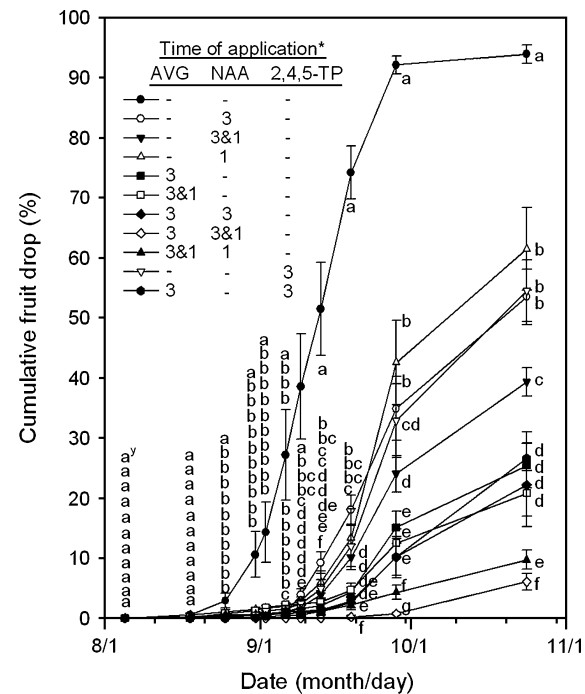

Fig. 1. Effects of aminoethoxyvinylglycine at 20 $\mathrm{mg} \cdot \mathrm{L}^{-1}$, naphthalene acidic acid at $125 \mathrm{mg} \cdot \mathrm{L}^{-1}$, and 2-(2,4,5-trichlorophenoxy) propionic acid $20 \mathrm{mg} \cdot \mathrm{L}^{-1}$ on preharvest fruit drop of 'Golden Supreme' apples. *Compounds were applied 3 and 1 weeks before the anticipated optimum harvest date. Data are means $\pm \operatorname{SE}(n=6)$. ${ }^{\mathrm{y}}$ Mean separation within columns by Duncan's multiple range test, $P<0.05$.

whereas AVG completely inhibited fruit ethylene production on 10 Nov.

On 28 Sept., only the combination of AVG, 1-MCP, and NAA had higher fruit firmness than control (Table 4). On 24 Oct., addition of AVG or 1-MCP slowed the loss of fruit firmness, whereas NAA enhanced it. Starch degradation was delayed by addition of AVG or 1-MCP. Addition of AVG or 1-MCP also decreased fruit background color. SSC was reduced only by the combination of AVG and NAA.

\section{Discussion}

Auxin reduces mature fruit or leaf drop by inhibiting ethylene-enhanced expression of the cellulase gene and de novo synthesis of cellulase (Tucker et al., 1988; Zur and Goren, 1977). Cellulase is an important hydrolytic enzyme involved in cell wall degradation and subsequent loosening or abscission of fruit and leaves. AVG, by contrast, delays preharvest fruit drop by inhibiting biosynthesis of ethylene and delaying the onset of apple fruit ethylene climacteric (Autio and Bramlage, 1982; Bangerth, 1978). In this study, applications of NAA and AVG 3 or $1 \mathrm{WBAH}$ effectively delayed preharvest fruit drop, and AVG had a more persistent fruit drop control effect than did NAA in both 'Golden Supreme' and 'Golden Delicious' apples. These results are in agreement with previous reports in other apple cultivars such as 'King of the Pippin' (Bangerth, 1978), 'McIntosh' (Greene, 2005; Schupp and Greene, 2004), 'Delicious' (Byers, 1997), and 'Arlet' (Byers et al., 2005). In 'Golden Supreme' apples, the combination of one application of AVG and two applications of NAA had much lower 
Table 1. Effects of aminoethoxyvinylglycine (AVG) at $125 \mathrm{mg} \cdot \mathrm{L}^{-1}$, naphthalene acidic acid (NAA) at $20 \mathrm{mg} \cdot \mathrm{L}^{-1}$, and 2-(2,4,5-trichlorophenoxy) propionic acid $(2,4,5-\mathrm{TP})$ at $20 \mathrm{mg} \cdot \mathrm{L}^{-1}$ on fruit ethylene production of 'Golden Supreme' apples $(\mathrm{n}=6)$

\begin{tabular}{|c|c|c|c|c|c|c|c|}
\hline \multirow{2}{*}{$\begin{array}{l}\text { Time of AVG } \\
\text { application (weeks } \\
\text { before harvest) }\end{array}$} & \multirow{2}{*}{$\begin{array}{l}\text { Time of NAA } \\
\text { application (weeks } \\
\text { before harvest) }\end{array}$} & \multirow{2}{*}{$\begin{array}{l}\text { Time of 2,4,5-TP } \\
\text { application (weeks } \\
\text { before harvest) }\end{array}$} & \multicolumn{5}{|c|}{ Fruit ethylene production $\left(\mu \mathrm{L} \cdot \mathrm{kg}^{-1} \cdot \mathrm{h}^{-1}\right)$} \\
\hline & & & 4 Aug. & 15 Aug. & 22 Aug. & 2 Sept. & 23 Sept. \\
\hline$\overline{-}$ & - & - & $0.01 \mathrm{a}^{\mathrm{z}}$ & $0.07 \mathrm{c}$ & $1.78 \mathrm{~b}$ & $64.44 \mathrm{~b}$ & $39.18 \mathrm{c}$ \\
\hline - & 3 & - & $0.01 \mathrm{a}$ & - & - & $60.1 \mathrm{~b}$ & $62.59 \mathrm{~b}$ \\
\hline 3 & - & - & $0.01 \mathrm{a}$ & $0.06 \mathrm{c}$ & $0.03 \mathrm{~d}$ & $0.01 \mathrm{~d}$ & $2.52 \mathrm{e}$ \\
\hline 3 and 1 & - & - & $0.01 \mathrm{a}$ & - & - & - & $2.52 \mathrm{e}$ \\
\hline 3 & 3 & - & $0.01 \mathrm{a}$ & - & - & $0.01 \mathrm{~d}$ & $23.98 \mathrm{~d}$ \\
\hline 3 & $3 \& 1$ & - & $0.01 \mathrm{a}$ & - & - & - & $5.40 \mathrm{e}$ \\
\hline 3 and 1 & 1 & - & $0.01 \mathrm{a}$ & - & - & - & $0.02 \mathrm{f}$ \\
\hline - & - & 3 & $0.01 \mathrm{a}$ & $1.879 \mathrm{a}$ & $23.87 \mathrm{a}$ & $114.46 \mathrm{a}$ & $86.75 \mathrm{a}$ \\
\hline 3 & - & 3 & $0.01 \mathrm{a}$ & $0.13 \mathrm{~b}$ & $0.23 \mathrm{c}$ & $8.35 \mathrm{c}$ & $87.07 \mathrm{a}$ \\
\hline
\end{tabular}

${ }^{2}$ Mean separation within columns by Duncan's multiple range test, $P<0.05$.

Table 2. Effects of aminoethoxyvinylglycine (AVG) at $125 \mathrm{mg} \cdot \mathrm{L}^{-1}$, naphthalene acidic acid (NAA) at $20 \mathrm{mg} \cdot \mathrm{L}^{-1}$, and 2-(2,4,5-trichlorophenoxy) propionic acid $(2,4,5-\mathrm{TP})$ at $20 \mathrm{mg} \cdot \mathrm{L}^{-1}$ on fruit weight, flesh firmness, and starch of 'Golden Supreme' apples $(\mathrm{n}=60)$.

\begin{tabular}{|c|c|c|c|c|c|c|c|c|c|c|c|}
\hline \multirow{2}{*}{$\begin{array}{l}\text { Time of AVG } \\
\text { application } \\
\text { (weeks before } \\
\text { harvest) }\end{array}$} & \multirow{2}{*}{$\begin{array}{c}\text { Time of NAA } \\
\text { application } \\
\text { (weeks before } \\
\text { harvest) }\end{array}$} & \multirow{2}{*}{$\begin{array}{c}\text { Time of 2,4,5-TP } \\
\text { application } \\
\text { (weeks before } \\
\text { harvest) }\end{array}$} & \multicolumn{3}{|c|}{ Fruit weight $(\mathrm{g})$} & \multicolumn{3}{|c|}{ Flesh firmness $(\mathrm{N})$} & \multicolumn{3}{|c|}{ Starch $(0-8)$} \\
\hline & & & 23 Aug. & 30 Aug. & 20 Sept. & 23 Aug. & 30 Aug. & 20 Sept. & 23 Aug. & 30 Aug. & 20 Sept. \\
\hline - & - & - & $174.0 \mathrm{ab}^{\mathrm{z}}$ & $202.1 \mathrm{ab}$ & $222.9 \mathrm{ab}$ & $94.9 \mathrm{ab}$ & $89.0 \mathrm{ab}$ & $76.3 \mathrm{~b}$ & $2.1 \mathrm{e}$ & $3.5 \mathrm{c}$ & $6.5 \mathrm{~b}$ \\
\hline - & 3 & - & $164.5 \mathrm{~b}$ & $195.0 \mathrm{abc}$ & $221.7 \mathrm{ab}$ & $94.0 \mathrm{abc}$ & $86.3 \mathrm{~b}$ & $70.4 \mathrm{c}$ & $3.0 \mathrm{bc}$ & $4.7 \mathrm{~b}$ & $7.8 \mathrm{a}$ \\
\hline - & 3 and 1 & - & $174.0 \mathrm{ab}$ & $190.2 \mathrm{abc}$ & $221.7 \mathrm{ab}$ & $94.0 \mathrm{abc}$ & $87.2 \mathrm{ab}$ & $70.8 \mathrm{c}$ & $3.1 \mathrm{bc}$ & $4.7 \mathrm{~b}$ & $7.9 \mathrm{a}$ \\
\hline - & 1 & - & $184.5 \mathrm{a}$ & $209.0 \mathrm{a}$ & $236.5 \mathrm{a}$ & $88.5 \mathrm{~cd}$ & $86.3 \mathrm{ab}$ & $69.0 \mathrm{c}$ & $2.4 \mathrm{de}$ & $3.6 \mathrm{c}$ & $7.9 \mathrm{a}$ \\
\hline 3 & - & - & $168.2 \mathrm{ab}$ & $195.0 \mathrm{abc}$ & $223.4 \mathrm{ab}$ & $93.1 \mathrm{abcd}$ & $91.7 \mathrm{ab}$ & $80.8 \mathrm{ab}$ & $2.1 \mathrm{e}$ & $2.1 \mathrm{~d}$ & $4.9 \mathrm{c}$ \\
\hline 3 and 1 & - & - & $167.2 \mathrm{~b}$ & $186.0 \mathrm{bc}$ & $224.5 \mathrm{ab}$ & $92.6 \mathrm{abcd}$ & $90.4 \mathrm{ab}$ & $80.4 \mathrm{ab}$ & $2.1 \mathrm{e}$ & $2.4 \mathrm{~d}$ & $4.8 \mathrm{c}$ \\
\hline 3 & 3 & - & $166.0 \mathrm{~b}$ & $187.0 \mathrm{cb}$ & $217.4 \mathrm{ab}$ & $91.7 \mathrm{abcd}$ & $88.5 \mathrm{ab}$ & $79.0 \mathrm{ab}$ & $3.1 \mathrm{bc}$ & $2.6 \mathrm{~d}$ & $6.1 \mathrm{~b}$ \\
\hline 3 & 3 and 1 & - & $161.0 \mathrm{~b}$ & $174.0 \mathrm{c}$ & $208.2 \mathrm{~b}$ & $97.2 \mathrm{a}$ & $93.1 \mathrm{a}$ & $83.5 \mathrm{a}$ & $2.8 \mathrm{~cd}$ & $2.6 \mathrm{~d}$ & $5.9 \mathrm{~b}$ \\
\hline 3 and 1 & 1 & - & $175.5 \mathrm{ab}$ & $194.0 \mathrm{abc}$ & $227.9 \mathrm{ab}$ & $94.0 \mathrm{abc}$ & $90.8 \mathrm{ab}$ & $79.0 \mathrm{ab}$ & $2.0 \mathrm{e}$ & $2.3 \mathrm{~d}$ & $4.5 \mathrm{c}$ \\
\hline - & - & 3 & $177.0 \mathrm{ab}$ & $200.0 \mathrm{ab}$ & $224.8 \mathrm{ab}$ & $87.2 \mathrm{~d}$ & $73.6 \mathrm{c}$ & $54.0 \mathrm{~d}$ & $4.5 \mathrm{a}$ & $6.4 \mathrm{a}$ & $8.0 \mathrm{a}$ \\
\hline 3 & - & 3 & $173.1 \mathrm{ab}$ & $196.0 \mathrm{ab}$ & $236.0 \mathrm{a}$ & $90.8 \mathrm{bcd}$ & $87.6 \mathrm{ab}$ & $66.7 \mathrm{c}$ & $3.5 \mathrm{~b}$ & $4.0 \mathrm{bc}$ & $7.4 \mathrm{a}$ \\
\hline
\end{tabular}

${ }^{\mathrm{z}}$ Mean separation within columns by Duncan's multiple range test, $P<0.05$.

Table 3. Effect of aminoethoxyvinylglycine (AVG) at $125 \mathrm{mg} \cdot \mathrm{L}^{-1}$, naphthalene acidic acid (NAA) at $20 \mathrm{mg} \cdot \mathrm{L}^{-1}$, and 2-(2,4,5-trichlorophenoxy) propionic acid $(2,4,5-\mathrm{TP})$ at $20 \mathrm{mg} \cdot \mathrm{L}^{-1}$ on soluble solids concentration, fruit background color, and stem end crack of 'Golden Supreme' apples $(\mathrm{n}=60)$

\begin{tabular}{|c|c|c|c|c|c|c|c|c|c|c|}
\hline \multirow{2}{*}{$\begin{array}{l}\text { Time of AVG } \\
\text { application (weeks } \\
\text { before harvest) }\end{array}$} & \multirow{2}{*}{$\begin{array}{l}\text { Time of NAA } \\
\text { application (weeks } \\
\text { before harvest) }\end{array}$} & \multirow{2}{*}{$\begin{array}{c}\text { Time of 2,4,5-TP } \\
\text { application (weeks } \\
\text { before harvest) }\end{array}$} & \multicolumn{3}{|c|}{ Soluble solids (\%) } & \multicolumn{3}{|c|}{ Fruit background color $(0-4)$} & \multicolumn{2}{|c|}{ Stem end crack (\%) } \\
\hline & & & 23 Aug. & 30 Aug. & 20 Sept. & 23 Aug. & 30 Aug. & 20 Sept. & 30 Aug. & 20 Sept. \\
\hline $\bar{Z}$ & - & - & $11.5 \mathrm{a}^{\mathrm{z}}$ & $12.3 \mathrm{ab}$ & $13.2 \mathrm{a}$ & $2.6 \mathrm{bc}$ & $3.1 \mathrm{~cd}$ & $3.6 \mathrm{c}$ & $0 \mathrm{a}$ & $1.4 \mathrm{~b}$ \\
\hline - & 3 & - & $11.1 \mathrm{ab}$ & $12.1 \mathrm{ab}$ & $12.8 \mathrm{abc}$ & $2.6 \mathrm{bc}$ & $3.2 \mathrm{~b}$ & $3.8 \mathrm{~b}$ & $0 \mathrm{a}$ & $5.7 \mathrm{ab}$ \\
\hline - & 3 and 1 & - & $11.3 \mathrm{ab}$ & $12.0 \mathrm{ab}$ & $12.2 \mathrm{~cd}$ & $2.6 \mathrm{bc}$ & $3.3 \mathrm{~b}$ & $3.8 \mathrm{~b}$ & $0 \mathrm{a}$ & $8.3 \mathrm{ab}$ \\
\hline - & 1 & - & $11.5 \mathrm{a}$ & $12.5 \mathrm{a}$ & $13.2 \mathrm{a}$ & $2.5 \mathrm{bcd}$ & $3.1 \mathrm{bc}$ & $3.9 \mathrm{ab}$ & $0 \mathrm{a}$ & $15.0 \mathrm{a}$ \\
\hline 3 & - & - & $11.5 \mathrm{a}$ & $12.2 \mathrm{ab}$ & $12.9 \mathrm{ab}$ & $2.6 \mathrm{bc}$ & $2.9 \mathrm{e}$ & $3.0 \mathrm{~d}$ & $0 \mathrm{a}$ & $0.0 \mathrm{c}$ \\
\hline 3 and 1 & - & - & $11.3 \mathrm{ab}$ & $12.0 \mathrm{ab}$ & $12.7 \mathrm{abc}$ & $2.6 \mathrm{bc}$ & $3.0 \mathrm{de}$ & $2.9 \mathrm{~d}$ & $0 \mathrm{a}$ & $0.0 \mathrm{c}$ \\
\hline 3 & 3 & - & $10.8 \mathrm{~b}$ & $11.0 \mathrm{c}$ & $11.5 \mathrm{e}$ & $2.6 \mathrm{~b}$ & $2.9 \mathrm{e}$ & $3.0 \mathrm{~d}$ & $0 \mathrm{a}$ & $0.0 \mathrm{c}$ \\
\hline 3 & 3 and 1 & - & $11.2 \mathrm{ab}$ & $11.7 \mathrm{~b}$ & $12.0 \mathrm{de}$ & $2.3 \mathrm{~d}$ & $3.0 \mathrm{de}$ & $3.0 \mathrm{~d}$ & $0 \mathrm{a}$ & $0.0 \mathrm{c}$ \\
\hline 3 and 1 & 1 & - & $11.4 \mathrm{a}$ & $11.7 \mathrm{~b}$ & $12.6 \mathrm{abcd}$ & $2.5 \mathrm{bcd}$ & $3.1 \mathrm{cde}$ & $2.9 \mathrm{~d}$ & $0 \mathrm{a}$ & $0.0 \mathrm{c}$ \\
\hline - & - & 3 & $11.4 \mathrm{a}$ & $12.2 \mathrm{ab}$ & $12.9 \mathrm{a}$ & $3.1 \mathrm{a}$ & $3.7 \mathrm{a}$ & $4.0 \mathrm{a}$ & $0 \mathrm{a}$ & $15.0 \mathrm{a}$ \\
\hline 3 & - & 3 & $11.1 \mathrm{ab}$ & $11.7 \mathrm{~b}$ & $12.3 \mathrm{bcd}$ & $2.4 \mathrm{~cd}$ & $3.1 \mathrm{cde}$ & $3.7 \mathrm{~b}$ & $0 \mathrm{a}$ & $1.7 \mathrm{~b}$ \\
\hline
\end{tabular}

${ }^{2}$ Mean separation within columns by Duncan's multiple range test, $P<0.05$.

preharvest fruit drop than did one or two applications of AVG alone, although there was no significant difference in fruit ethylene production among these treatments, indicating that there is a synergic effect between NAA and AVG in controlling preharvest fruit drop. This suggestion is supported by the results that the combination of $\mathrm{AVG}$ and NAA had higher fruit ethylene production but had less preharvest fruit drop compared with AVG alone in 'Golden Delicious' apples. Similarly, it has been suggested that the auxin flux across the abscission zone appears to determine the sensitivity of fruit to ethylene and the endogenous concentrations of auxin must fall below a certain threshold in the abscission zone to promote abscission
(Brown, 1997; Goren, 1993; Osborne, 1989; Yuan et al., 2001). Two applications of AVG led to higher fruit ethylene production on 23 Sept. than did the combination of two applications of AVG and one application of NAA. This suggests that NAA and AVG also had a synergistic effect on inhibition of fruit ethylene biosynthesis.

AVG and NAA are two registered compounds used to reduce preharvest fruit drop in apples. Commercially, AVG as the Retain formulation is used for drop control and to delay ripening $\approx 4$ weeks before harvest. However, in 'McIntosh' apples, Greene (2005) reported that AVG equally retarded preharvest fruit drop and delayed fruit ripening when applied between 1 and 4 weeks before the normal harvest of untreated trees. Similarly, in our study, AVG when applied 3 or 1 weeks before normal harvest date effectively suppressed fruit drop and maintained fruit quality in 'Golden Supreme' and 'Golden Delicious' apples. NAA is used commercially to delay preharvest fruit drop 1 or 2 weeks before harvest. Our results suggested that like AVG, the window for the application of NAA is quite wide, because one application of NAA made 3 weeks before normal harvest was as effective as that made 1 week before harvest in delaying preharvest fruit drop. Furthermore, two applications of NAA made 1 and 3 weeks before harvest were more effective than one application of NAA in delaying preharvest fruit drop. 


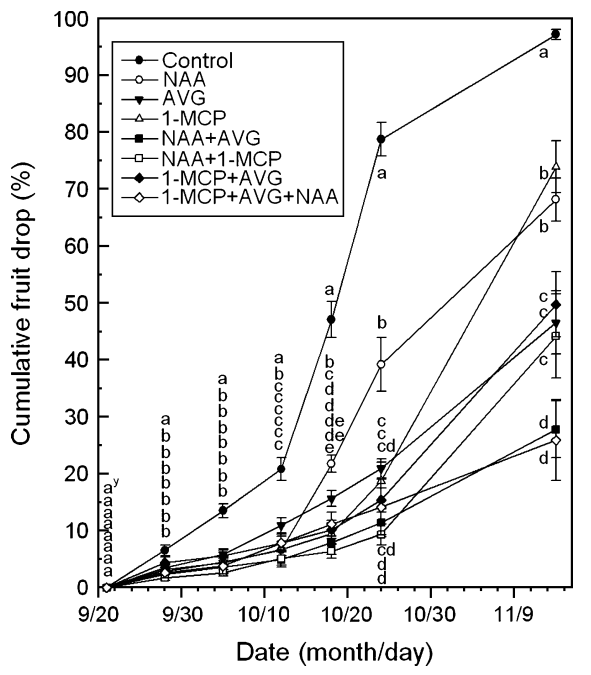

Fig. 2. Effects of 1-methylcyclopropane at 396 $\mathrm{mg} \cdot \mathrm{L}^{-1}$, aminoethoxyvinylglycine at $20 \mathrm{mg} \cdot \mathrm{L}^{-1}$, and naphthalene acidic acid at $20 \mathrm{mg} \cdot \mathrm{L}^{-1}$ on preharvest fruit drop of 'Golden Delicious' apples. Compounds were applied 1 week before the anticipated optimum harvest date. Data are means \pm SE $(n=6)$. ${ }^{y}$ Mean separation within columns by Duncan's multiple range test, $P<0.05$.

It is always a challenge to harvest a large portion of apple fruit in a short period of time as a result of compressed harvest periods for apples (Greene, 2005). Ten percent preharvest fruit drop is usually an arbitrary threshold for acceptable drop control (Greene and Schupp, 2004). Results from our investigation suggest that use of AVG and NAA alone or in combination to delay preharvest fruit drop may provide apple growers with the flexibility to harvest their apples with high quality. To delay preharvest fruit drop for a short period of time such as 1 to 3 weeks beyond normal harvest date, one or two applications of NAA or one application of AVG should be used. However, the combination of one application of AVG and two applications of NAA should be used for the retardation of preharvest fruit drop for more than 3 weeks beyond normal harvest date.

Like AVG (an inhibitor of ethylene biosynthesis), 1-MCP (an inhibitor of ethylene action) as the sprayable formulation effectively inhibited fruit ethylene production and delayed preharvest fruit drop in 'Golden

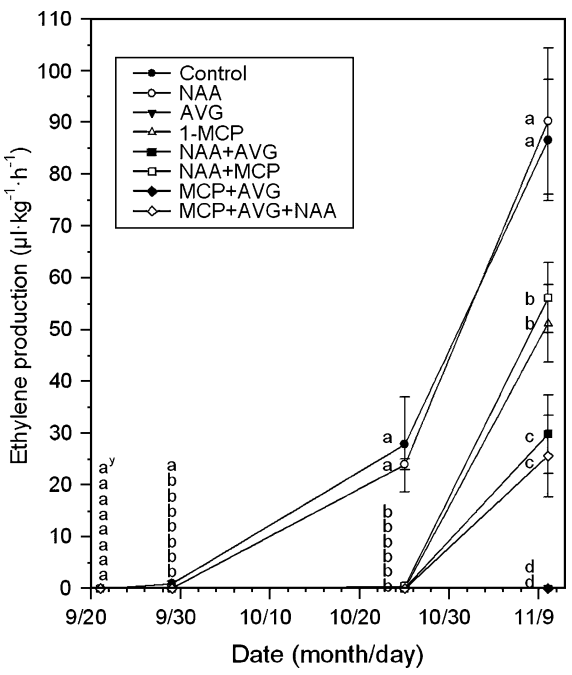

Fig. 3. Effects of 1-methylcyclopropane at $396 \mathrm{mg} \cdot \mathrm{L}^{-1}$, aminoethoxyvinylglycine at $125 \mathrm{mg} \cdot \mathrm{L}^{-1}$, and naphthalene acidic acid at $20 \mathrm{mg} \cdot \mathrm{L}^{-1}$ on fruit ethylene production in 'Golden Delicious' apples. Compounds were applied 1 week before the anticipated optimum harvest date. Data are means $\pm \operatorname{SE}(n=6) .{ }^{\mathrm{y}}$ Mean separation within columns by Duncan's multiple range test, $P<0.05$.

Delicious' apples. Similarly, 1-MCP (as the SmartFresh formulation) can effectively reduce ethephon-enhanced leaf and fruit drop in citrus (Pozo et al., 2004). However, Byers et al. (2005) reported that 1-MCP applied either as a gas or spray had no effect on preharvest fruit drop in 'Arlet' apples. This discrepancy could be the result of the difference in the formulation of 1-MCP. 1-MCP used in this study was a new, improved formulation that was sprayable. Therefore, more 1-MCP might enter the apple fruit or fruit abscission zone, bind the ethylene receptor sites in those tissues, and delay fruit drop as evidenced by reduced fruit ethylene production and delayed fruit ripening from 1-MCP-treated 'Golden Delicious' trees.

Our data also confirm previous reports that single or repeated applications of NAA stimulated fruit ripening, reduced flesh firmness, and enhanced starch degradation (Batjer and Moon, 1945; Marini et al., 1993), whereas AVG delayed fruit ripening and slowed loss of flesh firmness and degradation of starch (Autio and Bramlage, 1982;
Byers, 1997; Greene, 2005; Schupp and Greene, 2004). Addition of AVG or 1-MCP delayed NAA-enhanced fruit ripening and maturity. This is attributed to the action of AVG or 1-MCP in reducing NAA-stimulated ethylene production.

In conclusion, our results showed that the combinations of NAA (a synthetic auxin) and AVG (an inhibitor of ethylene biosynthesis) or 1-MCP (an inhibitor of ethylene action) was more effective when used in combination than when used alone in reducing preharvest fruit drop and extending the harvest season while maintaining fruit quality.

\section{Literature Cited}

Addicott, F.T. 1982. Abscission. Univ. California Press, Berkeley.

Autio, W.R. and W.J. Bramlage. 1982. Effects of AVG on maturation, ripening, and storage of apples. J. Amer. Soc. Hort. Sci. 107:10741077.

Bangerth, F. 1978. The effect of a substituted amino acid on ethylene biosynthesis, respiration, ripening and preharvest drop of apple fruits. J. Amer. Soc. Hort. Sci. 103:401-404.

Batjer, L.P. and H.H. Moon. 1945. Effect of naphthaleneacetic acid sprays on maturity of apples. Proc. Amer. Soc. Hort. Sci. 46:113117.

Blankenship, S. and J.M. Dole. 2003. 1-Methylcyclopropene: A review. Postharvest Biol. Technol. 28:1-25.

Brown, K.M. 1997. Ethylene and abscission. Physiol. Plant. 100:567-576.

Bukovac, M.J., F. Zucconi, R.P. Larsen, and C.D. Kesner. 1969. Chemical promotion of fruit abscission in cherries and plums with special reference to 2-chloroethylphosphonic acid. J. Amer. Soc. Hort. Sci. 94:226-231.

Byers, R.E. 1997. Effects of aminoethoxyvinylglycine (AVG) on preharvest fruit drop and maturity of 'Delicious' apples. J. Tree Fruit Production 2:53-75.

Byers, R.E., D.H. Carbaugh, and L.D. Combs. 2005. Ethylene inhibitors delay fruit drop, maturity, and increase fruit size of 'Arlet' apples. HortScience 40:2061-2065.

Byers, R.E. and D.R. Eno. 2002. Harvest date influences fruit size and yield of 'York' and 'Golden Delicious' apple trees. J. Tree Fruit Production 3:63-79.

Edgerton, L.J. and G.D. Blanpied. 1970. Interaction of succinic acid 2,2-dimethyl hydrazide, 2-chloroethlphosphonic acid and auxins on maturity, quality and abscission of apples. J. Amer. Soc. Hort. Sci. 95:664-666.

Table 4. Effects of 1-methylcyclopropene (1-MCP), aminoethoxyvinylglycine (AVG) at $125 \mathrm{mg} \cdot \mathrm{L}^{-1}$ and naphthalene acidic acid (NAA) at $20 \mathrm{mg} \cdot \mathrm{L}^{-1}$ on fruit quality and maturity in 'Golden Delicious' apples ${ }^{2}(\mathrm{n}=60)$.

\begin{tabular}{|c|c|c|c|c|c|c|c|c|c|c|c|c|}
\hline \multirow[b]{2}{*}{ Treatment } & \multicolumn{2}{|c|}{ Fruit diameter $(\mathrm{cm})$} & \multicolumn{2}{|c|}{ Fruit wt (g) } & \multicolumn{2}{|c|}{ Flesh firmness $(\mathrm{N})$} & \multicolumn{2}{|c|}{$\operatorname{Starch}(0-8)$} & \multicolumn{2}{|c|}{ Fruit background color } & \multicolumn{2}{|c|}{ Soluble solids $(\%)$} \\
\hline & 28 Sept. & 24 Oct. & 28 Sept. & 24 Oct. & 28 Sept. & 24 Oct. & 28 Sept. & 24 Oct. & 28 Sept. & 24 Oct. & 28 Sept. & 24 Oct. \\
\hline Control & $7.2 \mathrm{a}^{\mathrm{y}}$ & $7.6 \mathrm{~b}$ & $164.6 \mathrm{a}$ & $182.1 \mathrm{~b}$ & $76.7 \mathrm{~b}$ & $60.4 \mathrm{~b}$ & $5.3 \mathrm{a}$ & $7.6 \mathrm{~b}$ & $2.9 \mathrm{a}$ & $3.8 \mathrm{a}$ & $15.1 \mathrm{ab}$ & $17.4 \mathrm{ab}$ \\
\hline NAA & $7.4 \mathrm{a}$ & $7.9 \mathrm{a}$ & $172.6 \mathrm{a}$ & $205.9 \mathrm{a}$ & $76.7 \mathrm{~b}$ & $52.7 \mathrm{c}$ & $5.5 \mathrm{a}$ & $7.9 \mathrm{a}$ & $3.0 \mathrm{a}$ & $3.9 \mathrm{a}$ & $15.4 \mathrm{ab}$ & $17.7 \mathrm{a}$ \\
\hline AVG & $7.5 \mathrm{a}$ & $7.7 \mathrm{ab}$ & $173.0 \mathrm{a}$ & $192.9 \mathrm{ab}$ & $77.6 \mathrm{~b}$ & $67.7 \mathrm{a}$ & $4.3 \mathrm{c}$ & $7.2 \mathrm{c}$ & $2.9 \mathrm{a}$ & $3.5 \mathrm{~b}$ & $15.6 \mathrm{a}$ & $17.3 \mathrm{ab}$ \\
\hline 1-MCP & $7.3 \mathrm{a}$ & $7.8 \mathrm{ab}$ & $172.6 \mathrm{a}$ & $197.5 \mathrm{ab}$ & $78.5 \mathrm{ab}$ & $67.2 \mathrm{a}$ & $4.4 \mathrm{bc}$ & $6.6 \mathrm{~d}$ & $2.9 \mathrm{a}$ & $3.4 \mathrm{bc}$ & $14.9 \mathrm{ab}$ & $16.9 \mathrm{ab}$ \\
\hline $\mathrm{NAA}+\mathrm{AVG}$ & $7.4 \mathrm{a}$ & $7.7 \mathrm{ab}$ & $168.0 \mathrm{a}$ & $187.8 \mathrm{~b}$ & $77.6 \mathrm{~b}$ & $69.5 \mathrm{a}$ & $5.1 \mathrm{abc}$ & $7.6 \mathrm{~b}$ & $2.9 \mathrm{a}$ & $3.3 \mathrm{~cd}$ & $14.7 \mathrm{~b}$ & $16.4 \mathrm{~b}$ \\
\hline $\mathrm{NAA}+1-\mathrm{MCP}$ & $7.3 \mathrm{a}$ & $7.7 \mathrm{ab}$ & $170.1 \mathrm{a}$ & $196.2 \mathrm{ab}$ & $79.0 \mathrm{ab}$ & $67.2 \mathrm{a}$ & $5.1 \mathrm{abc}$ & $7.3 \mathrm{bc}$ & $2.9 \mathrm{a}$ & $3.4 \mathrm{bc}$ & $14.8 \mathrm{ab}$ & $16.7 \mathrm{ab}$ \\
\hline $1-\mathrm{MCP}+\mathrm{AVG}$ & $7.4 \mathrm{a}$ & $7.6 \mathrm{ab}$ & $169.1 \mathrm{a}$ & $186.0 \mathrm{~b}$ & $79.0 \mathrm{ab}$ & $69.0 \mathrm{a}$ & $4.5 \mathrm{bc}$ & $6.2 \mathrm{e}$ & $2.9 \mathrm{a}$ & $3.3 \mathrm{~cd}$ & $15.2 \mathrm{ab}$ & $17.2 \mathrm{ab}$ \\
\hline $\mathrm{NAA}+1-\mathrm{MCP}+\mathrm{AVG}$ & $7.4 \mathrm{a}$ & $7.7 \mathrm{ab}$ & $168.4 \mathrm{a}$ & $186.8 \mathrm{~b}$ & $80.8 \mathrm{a}$ & $68.1 \mathrm{a}$ & $4.4 \mathrm{bc}$ & $6.2 \mathrm{e}$ & $2.9 \mathrm{a}$ & $3.2 \mathrm{~d}$ & $15.3 \mathrm{ab}$ & $16.9 \mathrm{ab}$ \\
\hline
\end{tabular}

${ }^{2}$ Treatments were applied on 21 Sept. 2005.

${ }^{y}$ Mean separation within columns by Duncan's multiple range test, $P<0.05$. 
Fan, X., S.M. Blankenship, and J.P. Patteis. 1999 1-Methylcyclopropene inhibits apple ripening. J. Amer. Soc. Hort. Sci. 124:690-695.

Gardner, F.E., P.C. Marth, and L.P. Batjer. 1940 Spraying with plant growth substances for control of the preharvest drop of apples. Proc. Amer. Soc. Hort. Sci. 37:415-428.

Gardner, F.E., P.C. Reece, and G.E. Horanic. 1950 The effect of 2,4-D on preharvest drop of citrus under Florida conditions. Proc. Fla. State Hort. Soc. 63:7-11.

Goren, R. 1993. Anatomical, physiological, and hormonal aspects of abscission in citrus. Hort Rev. (Amer. Soc. Hort. Sci.) 15:145-182.

Greene, D.W. 2005. Time of aminoethoxyvinylglycine application influences preharvest drop and fruit quality of 'McIntosh' apples. HortScience 40:2056-2060.

Greene, D.W. and J.R. Schupp. 2004. Effects of aminoethoxyvinylglycine (AVG) on preharves drop, fruit quality, and maturation of 'Mcintosh' apples. II. Effects of timing and concentration relationships and spray volume. HortScience 39:1036-1041.

Jeong, J., D.J. Huber, and S.A. Sargent. 2002 Influence of 1-methylcyclopropene (1-MCP) on ripening and cell wall matrix polysaccharides of avocado. Postharv. Biol. Technol. 25:241-256.
Kluge, R.A. and A.P. Jacomino. 2002. Shelf life of peaches treated with 1-methylcyclopropene. Scientia Agricola 59:69-72.

Marini, R.P., R.E. Byers, and D.L. Sowers. 1993. Repeated applications of NAA control preharvest drop of 'Delicious' apples. J. Hort. Sci. 68:247-253.

Osborne, D.J. 1989. Abscission. Critical Rev. Plant Sci. 8:103-129.

Poapst, P.A., G.M. Ward, and W.R. Philips. 1959. Maturation of McIntosh apples in relation to starch loss and abscission. Can. J. Plant Sci. 39:257-263.

Pozo, L., R. Yuan, I. Kostenyuk, F. Alferez, G.Y Zhong, and J.K. Burns. 2004. Differential effects of 1-methylcyclopropane on citrus leaf and mature fruit abscission. J. Amer. Soc. Hort. Sci. 129:473-478.

Schupp, J.R. and D.W. Greene. 2004. Effect of aminoethoxyvinylglycine (AVG) on preharvest drop, fruit quality, and maturation of 'McIntosh' apples. I. Concentration and timing of dilute applications of AVG. HortScience 39:1030-1035.

Sisler, E.C. and M. Serek. 1997. Inhibitors of ethylene responses in plants at the receptor level: Recent developments. Physiol. Plant. 100:577-582.
Smock, R.M. and C.R. Gross. 1947. The effect of some hormone materials on the respiration and softening rates of apples. Proc. Amer. Soc. Hort. Sci. 49:67-77.

Tucker, M.L., R. Sexton, E. del Campillo, and L.N. Lewis. 1988. Bean abscission cellulose. Plant Physiol. 88:1257-1262.

Yuan, R., U. Hartmond, and W.J. Kender. 2001. Physiological factors affecting response of mature 'Valencia' orange fruit to $\mathrm{CMN}$ pyrazole. II. Endogenous concentrations of indole-3-acetic acid, abscisic acid, and ethylene. J. Amer. Soc. Hort. Sci. 126:420-426.

Yuan, R., U. Hartmond, and W.J. Kender. 2002. Naphthalene acetic acid and 2,3,5-triiodobenzoic acid affect the response of mature orange fruit to abscission chemicals. HortScience 37:348-352.

Yuan, R., W.J. Kender, and J.K. Burns. 2003. Young fruit and auxin transport inhibitors affect the response of mature 'Valencia' oranges to abscission materials via changing endogenous plant hormones. J. Amer. Soc. Hort. Sci. 128:302-308.

Zur, A. and R. Goren. 1977. Reducing preharvest drop of 'Temple' orange fruits by 2,4-D-Role of cellulose in the calyx abscission zone. Sci. Hort. 7:237-248. 